\title{
PENGARUH PENGGUNAAN PROBIOTIK YANG DIFERMENTASI DENGAN SUMBER KARBON YANG BERBEDA TERHADAP PERTUMBUHAN UDANG VANNAME (Litopenaeus vannamei)
}

\section{THE GROWTH OF WHITE SHRIMP (Litopenaeus vannamei) GIVEN PROBIOTIC CULTIVATED IN VARIOUS FERMENTED CARBON SOURCES}

\author{
Ika Citria $^{\left.1^{*}\right)}$, Zaenal Abidin ${ }^{1)}$, Baiq Hilda Astriana ${ }^{1)}$ \\ ${ }^{1)}$ Program Studi Budidaya Perairan, Universitas Mataram \\ Jl. Pendidikan No. 37 Mataram, NTB
}

\begin{abstract}
Abstrak
Penelitian ini bertujuan untuk mengetahui pengaruh penggunaan karbon yang berbeda dalam perbanyakan probiotik terhadap jumlah koloni bakteri, dan aplikasinya dalam pemeliharaan udang vanammei (Litopenaeus vannamei). Penelitian ini dilakukan di Balai Pengembangan Budidaya Perikanan Pantai (BPBPP) Sekotong, Lombok Barat. Sumber karbon yang digunakan dalam fermentesi bakteri probiotik adalah tapioka, dedak halus, dan jagung. Probiotik hasil perbanyakan kemudian diujikan ke udang post larva 20 untuk mengetahui tingkat pertumbuhan udang yang diberikan probiotik. Hasil penelitian menunjukkan bahwa jumlah koloni bakteri mengalami peningkatan yang lebih tinggi dari kontrol pada masing-masing media fermentasi yang dihitung pada hari ke-7dan hari ke 30. Penggunaan tapioka sebagai sumber karbon menghasilkan jumlah bakteri paling banyak yaitu $3.69 \times 10^{11} \mathrm{CFU} / \mathrm{ml}$ dibandingkan dengan sumber karbon dari dedak dan jagung. Hasil uji penggunaan probiotik tersebut ke udang menunjukkan bahwa probiotik dengan sumber karbon tapioka menghasilkan pertumbuhan harian udang tertinggi yaitu 4,36\% dibandingkan dengan dua probiotik lainnya.
\end{abstract}

Kata kunci : fermentasi probiotik, sumber karbon, udang vanname

\begin{abstract}
The goals of this study were to know the effect of utilization of various carbon sources fermented on growth of probiotic bacteria and to know the effect of the probiotic application on shrimp (Litopenaeus vannamei) growth. The experiment was conducted at Balai Pengembangan Budidaya Perikanan Pantai (BPBPP), West Nusa Tenggara. The probiotic bacteria werecultivated by using three different fermented carbon sources, i.e., fermented tapioca, fine bran, and corn meal. The bacteria then were tested to the postlarva 20 of shrimp. The result showed that all of the carbon sources increased the number of colony of bacteria on 7 th and 30th days. Tapioca as a carbon source resulted in the highest number of colony by $3.69 \times 10^{11} \mathrm{CFU} / \mathrm{ml}$ compared to fine bran and corn meal. The utilization of probiotic bacteria resulted from the multiplication showed that probiotic using tapioca as carbon source resulted in the highest growth rate compared with those of other carbon sources.
\end{abstract}

Keywords : probiotic fermentation, carbon sources, vannamei shrimp

*email korespondensi: Ika_citriaruslan@yahoo.com 


\section{Pendahuluan}

Penggunaan probiotik pada wadah pemeliharaan udang vaname umumnya ditujukan untuk memperbaiki kualitas air yaitu menguraikan bahan organik dari sisa pakan yang tidak dimakan oleh udang. Serta kotoran udang yang ada di dalam akuarium dapat diurai oleh probiotik (Muliani dkk., 2010). Selain itu juga probiotik dapat mengubah senyawa kompleks menjadi senyawa sederhana sehingga mudah dicerna oleh udang.Wang dkk (2008) dalam Arief (2012) menjelaskan bahwa bakteri probiotik menghasilkan enzim yang mampu mengurai senyawa kompleks menjadi sederhana sehingga siap digunakan udang. Adapun jenis probiotik yang ada di pasaran yang dapat digunakan secara langsung untuk kegiatan budidaya udang oleh masyarakat yaitu : probiotik Supper Ps, Mina Bacto, Super NB, Super Vamei, Vanna Pro dan EM4.

Harga probiotik pada kegiatan budidaya cukup mahal sehingga dapat menambah biaya produksi budidaya. Namun, probiotik dapat diperbanyak dengan cara fermentasi bahan baku yang diberikan pada media air budidaya, sehingga tidak terlalu menambah biaya produksi dalam budidaya. Hal ini sesuai dengan pernyataan Poernomo (2004) dalam Suwoyono dan Markus (2010), yang mengatakan bahwa saat ini probiotik untuk budidaya udang sudah tersedia secara komersial, penggunaan probiotik harus sesuai petunjuk aplikasi dan tergantung peruntukannya. Penggunaan probiotik akan menambah biaya produksi karena harga di pasaran cukup mahal, namun hal ini dapat ditekan dengan cara probiotik diperbanyak terlebih dahulu (Poernomo, 2004 dalam Suwoyono dan Markus, 2010).

Probiotik komersil yang digunakan dalam proses fermentasi dicampurkan dengan bahan baku sumber karbon seperti jagung, tapioka, dedak halus, dan tambahan lain seperti tepung ikan, molases. Bahan karbon mendukung dalam pertumbuhan bakteri karena mengandung karbohidrat dan protein. Wardah dan Tatang (2014) menyebutkan bahwa karbohidrat, protein, dan lipida merupakan komponen utama yang paling penting dalam metabolisme mikroba.

Bahan- bahan yang digunakan memiliki karbohidrat yang kompleks yaitu polisakarida yang tidak bisa digunakan langsung oleh mikroorganisme sehingga harus difermentasi dengan penambahan probiotik yang akan mengubah senyawa kompleks tersebut menjadi senyawa sederhana. Fermentasi dengan menggunakan bahan-bahan tersebut dapat menjadi salah satu upaya meningkatkan populasi bakteri probiotik.

Trismilah dan Sumaryanto (2005) menyatakan unsur karbon dapat meningkatkan energi dan biosintesis sehingga cukup untuk fermentasi. Bahan tepung tapioka, tepung jagung, dan dedak halus merupakan bahan kompleks yang akan diubah oleh bakteri menjadi bahan yang sederhana sehingga sebagai sumber karbon tidak perlu menggunakan bahan yang sederhana seperti glukosa ataupun gula. Pemberian probiotik yang dikombinasi dengan sumber karbon dapat meningkatkan populasi bakteri probiotik.

Pertumbuhan bakteri pada fermentasi probiotik bergantung dari bahan atau sumber karbon yang digunakan sebagai substrat dalam fermentasi probiotik. Hal ini dikarenakan substrat yang digunakan dapat mempengaruhi metabolisme bakteri. Sumber karbon yang berbeda dapat menghasilkan jumlah bakteri yang akan tumbuh berbeda. Zurriyati (1995) berpendapat bahwa hasil fermentasi terutama tergantung pada jenis bahan pangan (substrat), dan kondisi di sekelilingnya yang mempengaruhi pertumbuhan dan metabolisme mikroba tersebut.

Penelitian ini bertujuan untuk mengetahui pengaruh penggunaan karbon yang berbeda dalam perbanyakan probiotik terhadap jumlah koloni bakteri, dan aplikasinya dalam pemeliharaan udang vanammei (Litopenaeus vannamei).

\section{Metode Penelitian}

Penelitian ini dilaksanakan pada tanggal 22 Agustus sampai 30 September 2017 di Balai Pengembangan Budidaya Perikanan Pantai (BPBPP) Sekotong, Lombok Barat.

Pada Penelitian ini menggunakan metode eksperimental Rancangan Acak Lengkap (RAL) yaitu dengan 4 perlakuan yaitu $\mathrm{A}=$ Kontrol (Probiotik), B=Tapioka $80 \mathrm{~g}, \mathrm{C}$ $=$ Tepung dedak halus $80 \mathrm{~g}, \mathrm{D}=$ Tepung jagung $80 \mathrm{~g}$. 


\section{Proses Fermentasi}

Wadah fermentasi yang digunakan yaitu botol aqua 1 liter sebanyak 9 buah, botol film, dan plastik hitam. Proses fermentasi dilakukan dengan cara mencampur bahan sumber karbon sesuai perlakuan dan ulangan yang digunakan. Dedak halus $80 \mathrm{~g}$, tepung tapioka $80 \mathrm{~g}$, dan tepung jangung $80 \mathrm{~g}$ sebagai sumber karbon masing-masing dicampur dengan air laut, molase, tepung ikan, dan ragi. Bahan tersebut kemudian diaduk rata, dimasak selama 30 menit dan kemudian didinginkan untuk kemudian dicampur dengan probiotik super NB. Campuran bahan tersebut dimasukkan kedalam botol gelap volume 1 liter dan ditutup rapat. Botol disimpan pada tempat yang gelap selama 7 hari kemudian diaplikasikan ke udang. Probiotik hasil fermentasi diambil satu kali dalam 7 hari untuk diaplikasikan pada udang selama pemeliharaan.

\section{Pemeliharaan udang}

Ukuran benih yang digunakan PL20 dengan panjang $2 \mathrm{~cm}$. Setelah mendapatkan ukuran yang sama benih udang siap ditebar dan dipelihara. Benih dipelihara dengan kepadatan 30 ekor/bak dan diberi pakan buatan tiga kali sehari pada jam 07.00, 12.00, dan 16.00, sampai kenyang (ad libitum). Pemberian probiotik hasil fermentasi pada udang dilakukan tujuh hari sekali selama proses pemeliharaan 30 hari dengan konsetrasi $1 \mathrm{ml} / \mathrm{l}$. Pengukuran kualitas air dilakukan tujuh hari sekali selama proses pemeliharaan 30 hari. Penyiponan dilakukan setiap hari dengan jumlah air terbuang karena penyiponan sebanyak $2 \%$. Air yang keluar dari penyiponan kemudian diganti kembali dengan air laut baru.

Pengukur panjang udang dilakukan di awal dan di akhir pemeliharaan dengan cara mengukur semua udang yang hidup di bak kontainer.

\section{Pengumpulan Data}

\section{Pertumbuhuan koloni bakteri}

Penumbuhan koloni bakteri dilakukan pada hari ke-7 dan hari ke-30. Dimana hari ke7 merupakan pertama kali pengaplikasian probiotik pada udang dan hari ke-30 merupakan pengaplikasian probiotik terakhir pada udang.
Untuk menumbuhkan bakteri probiotik hasil fermentasi yang harus disiapkan adalah media penumbuhan (media padat). Media yang digunakan untuk penumbuhan bakteri probiotik adalah media PCA. Untuk menumbuhkan koloni bakteri diambil $1 \mathrm{ml}$ probiotik yang sudah difermentasi terlebih dahulu dan probiotik komersil untuk dilakukan pengenceran $10^{-1}$ sampai10 $10^{-10}$ Hasil pengenceran tersebut kemudian diambil $0,1 \mathrm{ml}$ tiap pengenceran untuk disebar ke cawan petri yang berisi media agar. Perhitungan jumlah koloni bakteri yang tumbuh dilakukan pada pengenceran $10^{-9}$. Perhitungan koloni dilakukan dengan rumus sebagai berikut: Koloni per $\mathrm{ml}=$ jumlah koloni per cawan $\mathrm{x}$ (1/pengenceran)

\section{Pertumbuhan udang}

Pertumbuhan panjang udang dapat diukur menggunakan penggaris dengan cara mengukur semua udang yang dipelihara. Pertumbuhan udang dihitung pada awal dan akhir pemeliharaan. Laju petumbuhan panjang harian dapat dihitung dengan rumus sebagai berikut (Zonneveld dkk, 1991) : $\alpha=(\sqrt[t]{(\text { lt }- \text { lo })-1}) \times 100 \%$ Dimana $: \alpha=$ Laju pertumbuhan harian panjang $(\%) ; \mathrm{l}_{\mathrm{t}}=$ Panjang rata-rata pada akhir perlakuan $(\mathrm{cm}) ; 1_{0}=$ Panjang rata-rata pada awal perlakuan $(\mathrm{cm})$.

\section{Survival rate $(\mathrm{SR})$}

SR menunjukan persentase benih yang hidup, berkembang, selama pemeliharaan hingga saat dipanen. SR dapat dihitung pada akhir pemeliharaan, Perhitungan SR menggunakan rumus $\mathrm{SR}=$ (jumlah akhir pengamatan/jumlah yang ditebar pada awal) $\mathrm{x}$ $100 \%$.

\section{Kualitas Air}

Pengukuran kualitas air dilakukan 7 hari sekali, parameter yang diukur terdiri dari suhu yaitu mengguanakan termometer, salinitas menggunakan refraktometer, $\mathrm{pH}$ menggunakan $\mathrm{pH}$ meter, DO menggunakan DO meter dan ammoniak menggunakan tes kit. 


\section{Hasil}

Laju pertumbuhan panjang harian udang (\%)

Hasil penelitian memperlihatkan bahwa penggunaan sumber karbon yang berbeda dalam fermentasi probiotik berpengaruh secara signifikan $(\mathrm{p}<0,05)$ terhadap pertumbuhan udang vanname. Hasil uji BNT $(\alpha=5 \%)$ menunjukkan bahwa pertumbuhan udang yang paling tinggi terdapat pada penggunaan probiotik yang difermentasi dengan sumber karbon tapioka yaitu sebesar 4,36\%, kemudian diikuti oleh perlakuan tepung jagung yaitu $4,20 \%$. Aplikasi probiotik yang telah diperbanyak dengan dedak dan probiotik kontrol menghasilkan pertumbuhan udang yang paling rendah yaitu masing masing $3.99 \%$ dan $4.10 \%$ (Gambar 1).

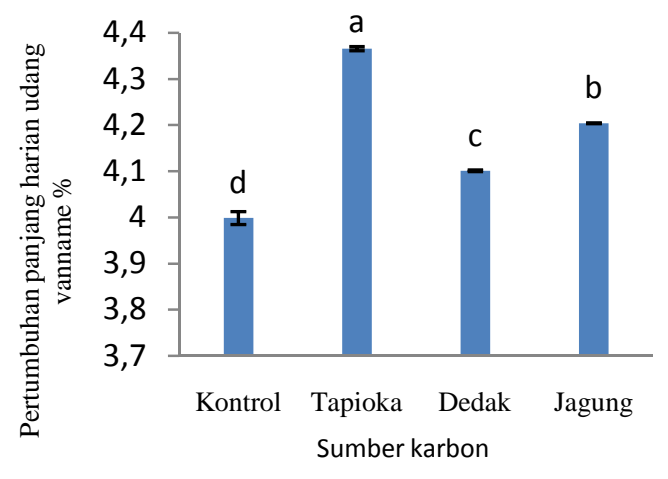

Ket : Huruf yang berbeda pada histogram menunjukan adanya perbedaan yang signifikan $(\mathrm{p}<0,05)$ terhadap pertumbuhan harian udang antar perlakuan.

Gambar 1. Laju Pertumbuhan harian panjang udang vanname (\%/hari).

\section{Jumlah koloni bakteri (CFU/ml)}

Jumlah koloni bakteri pada hari ke 7 menunjukkan hasil yang berbeda nyata $(\mathrm{p}<$ 0,05 ) antara perlakuan. Jumlah koloni bakteri pada fermentasi yang menggunakan tapioka adalah paling tinggi yaitu $3.69 \times 10^{11} \mathrm{CFU} / \mathrm{ml}$, sedangkan kontrol dan dedak memiliki jumlah koloni yang rendah yaitu masing-masing

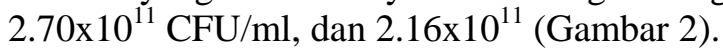

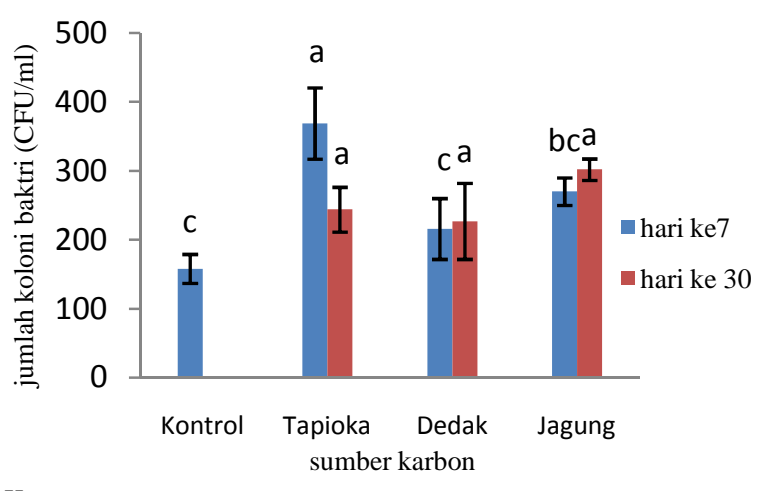

Ket. : Huruf yang berbeda pada histogram menunjukan adanya perbedaan yang signifikan $(\mathrm{p}<0,05)$ antar perlakuan .

Gambar 2. Pertumbuhan koloni bakteri (CFU/ml)

\section{Survival Rate (SR)}

Penggunaan probiotik kontrol maupun hasil fermentasi tidak memberikan pengaruh yang berbeda nyata $(\mathrm{p}<0,05)$ sehingga tingkat kelangsungn hidup udang vaname mencapai $100 \%$. Hal ini terlihat dari tidak adanya kematian selama pemeliharaan.

\section{Kualitas Air}

Hasil pengukuran kualitas air selama 30 hari pemeliharaan udang menunjukkan masih dalam kisaran yang optimal (Tabel 1).

\section{Pembahasan}

Pertumbuhan panjang harian udang yang diberi probiotik hasil fermentasi dengan sumber karbon yang berbeda lebih baik dari perlakuan kontrol (probiotik tanpa fermentasi). Perbedaan pertumbuhan udang dapat dikarenakan jumlah bakteri dalam media fermentasi berbeda seperti pada Gambar 2 sehingga menghasilkan pertumbuhan udang yang berbeda pula. Rendahnya pertumbuhan bakteri pada perlakuan kontrol disebabkan karena bakteri yang dihasilkan juga lebih rendah dari pada probiotik yang telah difermentasi. Bakteri probiotik pada kontrol hanya menggunakan bahan organik yang tersedia secara alami di air untuk memperbanyak diri sedangkan pada perlakuan lainnya terdapat bahan organik yang sengaja ditambahkan sebagai sumber karbon untuk menghasilkan energi bagi bakteri dalam memperbanyak koloninya. Menurut Avnimelech (1999), bakteri dan mikroorganisme menggunakan karbohidrat 
Tabel 1. Kualitas air

\begin{tabular}{lccccc}
\hline \multirow{2}{*}{ Parameter } & \multicolumn{4}{c}{ Pelakuan } & \multirow{2}{*}{ Kisaran optimum } \\
\cline { 2 - 5 } & $\mathrm{A}$ & $\mathrm{B}$ & $\mathrm{C}$ & $\mathrm{D}$ & \\
\hline Suhu $\left({ }^{0} \mathrm{C}\right)$ & $25.1-26.7$ & $25.2-27.6$ & $25.2-27.6$ & $25.2-27.6$ & $16-32$ (Cholik, 1998) \\
D0 $(\mathrm{mg} / \mathrm{L})$ & $4.28-5.78$ & $4.5-5.79$ & $4.19-5.59$ & $4-5.5$ & $>3 \mathrm{mg} /$ (Haliman, 2005) \\
$\begin{array}{l}\text { Salinitas } \\
(\mathrm{mg} / \mathrm{L})\end{array}$ & $30-35$ & $30-35$ & $30-35$ & $30-35$ & $30-53$ (Gunarto, 2007) \\
pH & $8-9$ & $8-9$ & $8-9$ & $8-9$ & \\
$\begin{array}{l}\text { Amoniak } \\
(\mathrm{mg} / \mathrm{L})\end{array}$ & $0.068^{\mathrm{a}}$ & $0.035^{\mathrm{b}}$ & $0.067^{\mathrm{a}}$ & $0.065^{\mathrm{a}}$ & $\begin{array}{c}\text { a } \\
\text { (Adiwijaya dkk., 2003) }\end{array}$ \\
\hline
\end{tabular}

(gula, pati dan selulosa) sebagai makanan untuk menghasilkan energi dan tumbuh melalui pembentukan protein dan sel-sel baru.

Pemanfaatan probiotik dengan jumlah bakteri yang berbeda akibat penambahan sumber karbon dalam pemeliharaan udang menghasilkan pertumbuhan yang berbeda. Pada penelitian Hadi dkk. (2006) kombinasi probiotik dengan sumber karbon memberikan hasil terbaik selama pemeliharaan yaitu pertumbuhan rata-ratanya $0,97 \pm \quad 0,06$ gram/hari sedangkan pemberian probiotik saja pertumbuhan rata-ratanya $0,86 \pm 0,06$.

Pertumbuhan udang tertinggi terdapat pada perlakuan penambahan tapioka.Tingginya pertumbuhan udang pada penambahan tapioka dikarenakan jumlah koloni bakteri yang dihasilkan saat fermentasi juga tinggi. Hal yang sama ditemukan oleh Suwoyono dkk. ( 2012) bahwa kombinasi probiotik dengan sumber karbon tapioka memberikan pertumbuhan panjang harian (\%) udang tertinggi yaitu $6,446 \pm 0,202$ dari pada tanpa penambahan sumber karbon yaitu $5,963 \pm 0,491$.

Pertumbuhan udang pada penambahan tepung jagung dan dedak lebih rendah dari penambahan tapioka yang kemungkinan disebabkan karena jumlah bakteri dalam probiotik yang digunakan tidak sebanyak pada penambahan tapioka. Tapioka memiliki jumlah sumber karbon paling banyak dibanding bahan sumber karbon lain yaitu sebesar 86,9\% untuk setiap $100 \mathrm{~g}$ bahan (Murtidjo, 2002) sehingga mempengaruhi jumlah koloni bakteri yang tumbuh.

Jumlah bakteri probiotik yang diberikan dalam pemeliharaan udang dapat berpengaruh terhadap pertumbuhan udang, dimana bakteri tersebut dapat membantu memperbaiki kualitas air dan proses pencernaan usus udang, sehingga memberikan pertumbuhan yang baik. Efek tersebut muncul jika jumlah bakteri hidup sampai di saluran pencernaan lebih dari $10^{6} \mathrm{CFU} / \mathrm{ml}$ (Kurman dan Rasic, 1991 dalam Shimakawa dkk., 2003 ). Menurut Irianto (2003) probiotik dapat mengatur jumlah mikrobia pada usus, menghalangi mikroorganisme patogen dalam usus dengan melepas enzim yang membantu proses pencernaan makanan sehingga dapat mempercepat pertumbuhan udang. Aktivitas enzim dalam pencernaan udang mampu membantu pemecahan bahan nutrien seperti karbohidrat, lemak, dan protein dalam pencernaan udang sehingga menyebabkan peningkatan pertumbuhan udang. Menurut Irianto (2003) bakteri dalam saluran pencernaan udang akan mensekresikan enzimenzim pencernaan seperti protease dan amylase.

Populasi bakteri probiotik yang terlalu tinggi juga dapat menimbulkan persaingan sesama jenis bakteri dalam pengambilan nutrisi atau substrat dalam saluran pencernaan sehingga saluran pencernaan terhambat dan sekresi enzim pun menurun (Atlas dan Richard 1993; Gatesoupe 1999 dalam Anggriani dkk., 2012).

Jumlah koloni bakteri pada penambahan tapioka hari ke-7 yaitu $3.69 \times 10^{11} \mathrm{CFU} / \mathrm{ml}$ sudah tergolong tinggi. Putra dkk. (2014) menyebutkan bahwa jumlah total koloni bakteri $2,4 \mathrm{x} \quad 10^{5} \mathrm{CFU} / \mathrm{ml}$ sudah dikatakan tinggi.

Jumlah koloni bakteri pada penambahan jagung dan penambahan dedak pada hari ke-7 sangat rendah yaitu $2.70 \times 10^{11} \mathrm{CFU} / \mathrm{ml}$, dedak $2.16 \times 10^{11} \mathrm{CFU} / \mathrm{ml}$, namun pada hari ke-30 jagung dan dedak mengalami peningkatan yaitu $2.27 \times 10^{11} \mathrm{CFU} / \mathrm{ml}$ dan $3.02 \times 10^{11}$ $\mathrm{CFU} / \mathrm{ml}$. Hal ini disebabkan pada awal fermentasi dengan penambahan sumber karbon jagung dan dedak, bakteri masih 
beradaptasi dengan lingkungan. Menurut pendapat Darwis dkk. (2008) bahwa pada awal fermentasi aktifitas enzim masih sangat rendah. Aktivitas enzim akan meningkat sejalan dengan bertambahnya waktu fermentasi dan menurun pada hari ke-10. Selain itu, kandungan energi yang tinggi, protein kasar, lemak kasar, dan bahan kering yang terkandung dalam jagung dan dedak mempengaruhi pertumbuhan bakteri (Kiay,2014). Kandungan serat kasar yang dimiliki jagung dan dedak lebih tinggi dibanding tapioka. Kandungan serat kasar jagung $1,63 \%$, lemak kasar $7,78 \%$, protein kasar 7,35\% dan bahan ekstrak tanpa nitrogen (BETN) 81,35\% (Umam dkk., 2014). Pada kandungan dedak bahan keringnya $86,5 \%$, protein kasar $10,8 \%$, serat kasar $11,5 \%$, lemak $5,1 \%$, bahan ekstrak tanpa nitrogen (BETN) 50,4\% (Garsetiasih dkk., 2003 dalam Indah, 2016). Sedangkan tapioka hanya memiliki $2 \%$ kandungan serat kasar. Dimana, bahan kering dan serat kasar yang cukup tinggi pada jagung dan dedak membutuhkan waktu lama untuk difermentasi oleh bakteri sehingga peningkatannya jumlah koloninya terjadi dalam rentang waktu yang lebih lama. Menurut Tilman, dkk (2005), kadar Serat kasar yang terlalu tinggi dalam suatu bahan akan menyebabkan kecernaan nutrien akan semakin lama.

Jumlah koloni bakteri pada hari ke 30 tidak terdapat perbedaan yang signifikan antar perlakuan, dikarenakan jumlah sumber energi yang tersedia dalam fermentasi berkurang seiring lamanya waktu fermentasi. Menurut Mades dkk. (2013) Semakin lama waktu fermentasi maka nutrisi yang tersedia selama proses fermentasi akan habis dimanfaatkan oleh bakteri. Oleh sebab itu, dilakukan fermentasi ulang seperti tahap pertama fermentasi. Pada penelitian Nurbaya (2012), melakukan fermentasi probiotik selama 7 hari dengan jumlah bakteri yang dihasilkan mengalami peningkatan yang puncaknya terjadi pada hari ke-6 dengan jumlah bakteri $10^{9}-10^{11} \mathrm{CFU} / \mathrm{ml}$, namun pada hari ke 7 mengalami penurunan. Sedangkan pada penelitian Ferdaus dkk. (2008) tentang waktu fermentasi terhadap perolehan asam laktat dari kulit pisang menghasilkan jumlah bakteri meningkat sampai pada hari ke 20 dan untuk waktu fermentasi yang lebih lama dari 20 hari, tidak ada peningkatan jumlah bakteri.
Survival rate merupakan tingkat kelangsungan hidup selama pemeliharaan mulai dari ditebar benih sampai panen.Kelangsungan hidup udang vanname selama pemeliharaan tidak berbeda antar perlakuan dikarenakan selama pemeliharaan, udang tidak mengalami kematian sehingga SR nya $100 \%$. Tingginya tingkat SR didukung oleh pemberian probiotik hasil fermentasi. Probiotik dapat memperbaiki kualitas air dan ketahanan tubuh udang sehingga tidak mudah terserang penyakit. Kualitas air selama pemeliharaan sangat baik dan mendukung untuk kehidupan udang vanname sehingga tidak ada faktor yang dapat menyebabkan kematian selama pemeliharaan.

Kisaran suhu yang diperoleh selama penelitian adalah $25,1-27,6^{\circ} \mathrm{C}$. Nilai suhu tersebut merupakan kisaran optimal bagi pertumbuhan udang vanname. Haliman dan Adijaya (2005) mengemukakan bahwa suhu yang optimal untuk pertumbuhan udang vannamei berkisar dari $25-32^{\circ}$ C.Kandungan oksigen terlarut selama penelitian berkisar antara 4-5.79 mg/l. (Clifford 1998 dalam Gunarto dkk 2009), melaporkan bahwa level DO minimum untuk kesehatan udang 3,0 mg/l dan DO yang potensial menyebabkan kematian adalah $<2,0 \mathrm{mg} / \mathrm{l}$. Derajat keasaman (pH) pada bak pemeliharaan selama penelitian adalah 8-9 untuk semua perlakuan. Haliman dan Adijaya (2005) mengemukakan bahwa $\mathrm{pH}$ yang ideal untuk udang vaname berkisar dari 7,5 dan 8,5. Salinitas air pada awal penebaran $30 \mathrm{ppt}$ disetiap bak dan setiap minggunya meningkat hingga mencapai 35 ppt. Haliman dan Adijaya (2005) mengemukakan bahwa udang vaname muda yang berumur 1-2 bulan memerlukan kadar garam 15-25 ppt agar pertumbuhannya dapat optimal, setelah umurnya lebih dari 2 bulan, dan pertumbuhan relatif baik pada kisaran salinitas 5-30 ppt.

Pemberian probiotik dapat menurunkan kisaran ammonia.Kandungan ammonia tinggi dapat dikarenakan sisa pakan dan feses udang yang menumpuk didalam air pemeliharaan. Amonia sangat berbahaya bagi kehidupan udang karena dapat menyebabkan kematian pada udang. Probiotik mampu menurunkan kadar ammonia yang tinggi dalam tambak. Boyd (1990) mengemukakan bahwa ammonia akan diubah menjadi nitrit oleh adanya aktivitas bakteri Nitrosomonas sp. dan selanjutnya nitrit akan segera diubah menjadi 
nitrat oleh adanya aktivitas bakteri Nitrobacter $s p$. Kondisi optimal untuk kedua proses tersebut adalah apabila jumlah oksigen mencukupi, kapasitas buffer baik, pH netral, dan suhu air rendah. Sedangkan Menurut Suwoyo (2010), probiotik Bacilus sp. dan Pseudomonas sp. mampu mengurai bahan organik sisa pakan dan feses secara cepat sehingga tidak terjadi akumulasi yang berlebihan di dasar tambak

Rata-rata kandungan amonia pada kontrol $0.068 \mathrm{mg} / \mathrm{l}$, tapioka $0.035 \mathrm{mg} / \mathrm{l}$, dedak 0,067 $\mathrm{mg} / \mathrm{l}$, dan jagung $0.065 \mathrm{mg} / \mathrm{l}$. Kandungan amonia pada pemberian probiotik yang menggunakan sumber karbon tapioka adalah paling rendah dibandingkan dengan penggunaan probiotik lainnya. Meskipun demikian kandungan ammonia diatas masih dapat ditolerir oleh udang. Menurut Boyd (1990) kandungan ammonia yang aman bagi kehidupan udang adalah dibawah 0,1 ppm, sedangkan Adiwijaya dkk. (2003) menyebutkan bahwa konsentrasi ammonia yang optimal udang vaname adalah $0,03-0,25$ ppm.

\section{Kesimpulan}

Tapioka sebagai sumber karbon dalam fermentasi probiotik menghasilkan jumlah koloni bakteri probiotik yang lebih tinggi dibandingkan dengan penggunaan tepung jagung dan dedak. Aplikasi hasil perbanyakan bakteri probiotik yang menggunakan tapioka sebagai sumber karbon dalam pemeliharaa udang menghasilkan pertumbuhan yang lebih tinggi dan amonia yang lebih rendah dibandingkan dengan probiotik yang diperbanyak dengan menggunakan dedak dan tepung jagung untuk pemeliharaan udang vanname.

\section{Daftar Pustaka}

Adiwijaya, D., Sapto, P.R., Sutikno, E., Sugeng., Subiyanto. (2003). Budidaya Udang Vaname (Litopenaeus vannamei) Sistem Tertutup yang Ramah Lingkungan. Departemen Kelautan dan Perikanan, Balai Besar Pengembangan Budidaya Air Payau, Jepara, 29 hlm.

Anggriani, R., Iskandar.,Taofikurahman, A. (2012). Efektifitas Penambahan Bacillus Sp. Hasil Isolasi dari Saluran Pencernaan Ikan Patin pada Pakan Komersial terhadap Kelangsungan Hidup dan
Pertumbuhan Benih Ikan Nila Merah (Oreocromis Niloticus). Jurnal Perikanan dan Kelautan. 3(3):75-83.

Arief, M., Fitriani, N., Subekti, S. (2014). Pengaruh Pemberian Probiotik Berbeda pada Pakan Komersial terhadap Pertumbuhan dan Efisiensi Pakan Ikan Lele Sangkuriang (Clarias sp.). Jurnal Ilmiah Perikanan dan Kelautan.Vol.6 (1).

Avnimelech, Y., \& Kochva. (1999). Carbon/Nitrogen Ratio as a Control Element in Aquaculture Systems. Aquaculture, 176: 227-235.

Boyd, C. E. (1990). Water Quality in Pond Aquaculture. Birmingham Publising. Alabama. 482. Penaeus Monodon Cultivatedin Thailand. Dis Aquat Org 60: 89-96, 2004.

Darwis, A.A., Sailah, I., Irawadi, T. T., Safriani. (1995). Kajian Kondisi Fermentasi pada Produksi Selulase dari Limbah Kelapa Sawit (Tandan Kosong dan Sabut) oleh Neurospora Sitophila. Jurnal Tenknologi Industry Pertanian Vol. 5(3) 199-207. cetak

Effendi, M. I. (2002). Biologi Perikanan. Yayasan Pustaka Nusatama. Yogyakarta.

Ferdaus, F., Wijayanti, M. O., Retnoningtyas, E. S., Irawati, W. (2008). Pengaruh Ph Konsentrasi Substrat, Penambahan Kalsium Karbonat dan Waktu Fermentasi terhadap Perolehan Asam Laktat dari Kulit Pisang. Fakultas Tehnik. Unversitas Katolik Mandala Widia. Surabaya.

Gunarto., A. Mansyur., \& Muliani. 2009. Aplikasi Dosis Fermentasi Probiotik Berbeda pada Budidaya Udang Vanname (Litopanneous Vannamei). Jurnal Ris. Akuakultur Vol 4. No 2: 241-255.

Fifendy, M., Eldini., Irdawati. 2013. Pengaruh Pemanfaatan Molasses terhadap Jumlah Mikroba dan Ketebalan Nata Pada The Kombucha. Universitas Lampung.

Hadi, S. P., \& Harris, E. (2006). Pengaruh Pemberian Sukrosa sebagai Sumber Karbon dan Probiotik terhadap Dinamika Populasi Bakteri dan Kualitas Air Media Budidaya Udang Vannamei (Litopaneaus Vannamei). Jurnal Akuakultur Indonesia. 5(2): 1790190.

Haliman, R.W., \& Dian. A. (2005). Udang Vannameii. Penebar Swadaya.

Ilmiah, S. N., Dwyana, Z., Abdullah, A. (2015). Kultur Probiotik pada Media 
Fermentasi Alami dalam Menghambat Pertumbuhan Vibrio Spp. The Effectiveness of The Antimicrobes of Probiotic Culture At The Natural Fermentation Media In Inhibiting The Growth Of The Growth Vibrio Spp. Universitas. Hasanudin. Makasar

Indah, S. A. (2016). Kandungan Protein Kasar dan Serat Kasar Silase Pakan Lengkap Berbahan Utama Batang Pisang (Musa Paradisiaca) dengan Lama Inkubasi yang Berbeda. Program Sarjana. Universitas Hasanudin. Makassar.

Irianto, A., \& Austin, B. (2002). Probiotics In Aquaculture. Journal of Fish Diseases. 25: 1 -10.

Irianto. A. 2003. Probiotik Aquacultere. Cetakan I. Gadjah Mada Universitas Press. Bulaksumur.Yogyakarta. $125 \mathrm{hlm}$.

Kiay, M. Z. (2014). Level Penambahan Tepung Daun Lamtoro (Leucaena leucocephala) dalam Ransum untuk Meningkatkan Kualitas Kuning Telur Puyuh. Fakultas Peternakan Universitas Gorontalo. Gorontalo.

Lestari, S. F., Yuniarti, Z., Abidin, Z. (2013). Pengaruh Formulasi Pakan Berbahan Baku Tepung Ikan, Tepung Jagung, Dedak Halus dan Ampas Tahu terhadap Pertumbuhan Ikan Nila (Oreocromis Sp). Jurnal Kelautan. Vol.6.No.1.

Mansyur, A., \& Tangko, A. M . (2008). Probiotik: Pemanfaatan untuk Pakan Ikan Berkualitas Rendah. Media Akuakultur.Balai Riset Perikanan Budidaya Air Payau, Maros. Vol 3, No, 2, 2008: 145-148.

Muliani., Nurbaya., Atmomarsono, M. (2010). Penggunaan Probiotik pada Pemeliharaan Udang Windu ( Paneous mondon) dengan Dosis Pakan yang Berbeda. Balai Riset Perikanan Budidaya Air Payau. Sulawesi Selatan.

Murtidjo, A. B. (2002). Pengawetan Dan Pemanfaatan Telur. PT. Penebar Swadaya. Jakarta.

Nurbaya., \& Muliani. (2012). Pertumbuhan Bakteri Probiotik pada Media Biakan Murni (Nutrient Broth) Dan Media Fermentasi. Balai Penelitian Budidaya Air Payau.Seminar Nasional Tahun IX. Hasil Penelitian Perikanan dan Kelautan.

Putra, A. N. (2010). Kajian Probiotik, Prebiotik dan Sanbiotik untuk
Meningkatkan Kinerja Pertumbuhan Ikan Nila (Oreochromis niloticus). Tesis. IPB: Bogor. 109).

Putra, S. J. W., Ninisupardjo, M., Widyorini, N. (2014). Analisis Hubungan Bahan Organik dengan Total Bakteri pada Tambak Udang intensif System Semibioflok di BBPBAP Jepara. Journal Of Maquares. Vol 3(3).

Sa'adah , Z., Noviana, I. S., Abdullah. (2008). Produksi Enzim Selulase oleh Aspergillus niger Menggunakan Substrat Jerami dengan Sistem Fermentasi Padat. (Online), (http://eprints.undip.ac.id, Diunduh 12 april 2018).

Shimakawa, Y. A., Matsubara. S., Yuki. N., Ikeda. M. Ishikwa. F. (2003).Evalution Of Bividobacterium Brece Stein Yakult Fermented Soymilk as Probiot. Ics Food. Int. Journal Food. Mocrobiology. 81(2003) 131-136.

Suwoyono, H. S. dan Mangampa, M. (2010). Aplikasi Probiotik dengan Konsentrasi Berbeda pada Pemeliharaan Udang Vannamei (Litopaneous Vannamei).Riset Balai Perikanan Budidaya Air Payau. Sulawesi Selatan :239-347.

Suwoyono, H. S., Mansyur, A., Gunarto. (2012). Penggunaan Sumber Karbon Organik pada Budidaya Udang Vaname (Litopenaeus Vannamei) dengan Teknologi Bioflok.Prosiding Indoaqua Forum Inovasi Teknologi Akuakultur. Balai Penelitian dan Pengembangan Budidaya Air Payau.

Tilman, A. D. H., Hartadi, S., Reksohadiprjo. (2005). Ilmu Makanan Ternak Dasar. Yogyakarta.

Trismilah Dan Sumaryanto. 2005. Pengaruh Kadar Nitrogen dalam Media pada Pembuatan Protease Menggunakan Bacillus Megaterium DSM319. Jurnal Ilmu Kefarmasian Indonesia. 3(1) : 9-12.

Waluyo, L. (2010). Teknik Metode Dasar Mikrobiologi. Penertbit UMM pres

Wardah dan Tatang S. (2014). Mikrobiologi Pangan. Penerbit ANDI.

Zonneveld, N., Huisman, E. A. Boon,J. H. (1991). Budidaya ikan. Gramedia: jakarta

Zuhri, R., Agustin, A. dan Rilda, Y. (2013). Pengaruh Sumber Karbon dan Nitrogen terhadap Produksi Protease Alkali dan 
Jurnal Perikanan (2018) Volume 8. No. 1.: 14-22

Bacillus sp. M.123 $_{123}$ Termofilik. Jurnal Biologika.Vol.2(1).

Zurriyati. (1995). Isolasi dari Biovicop Hitomega Sebagai Probiotik. Artikel. Lembaga Ilmu Pengetahuan Inonesia. Jakarta 